\title{
RARE DIAGNOSIS OF EBSTEIN ANOMALY IN AN ADULT PATIENT IN NORTHERN RIO DE JANEIRO
}

\section{Diagnóstico RARO DA ANOMALIA DE EBSTEIN NO NORTE DO RIO DE JANEIRO EM UM PACIENTE ADULTO}

\author{
Rogerio Muylaert de Carvalho Britto ${ }^{1}$, Adail Orrith Liborio Neto², \\ Otávio Defanti Ramos ${ }^{1}$, Mirelle da Silva Cruz Defanti ${ }^{1}$
}

Clin Biomed Res. 2021;41(2):178-180

1 Faculdade de Medicina de Campos. Campos dos Goytacazes, RJ, Brasil.

2 Faculdade de Medicina, Universidade Federal do Rio de Janeiro. Macaé, RJ, Brasil.

Corresponding author: Adail Orrith Liborio Neto adail_orrith@hotmail.com Faculdade de Medicina, Universidade Federal do Rio de Janeiro Campus Macaé

Rua Aloízio da Silva Gomes, 50 27930-560, Macaé, RJ, Brasil.

\section{ABSTRACT}

Ebstein anomaly is the fourth most frequent cyanotic heart disease in the neonatal period, and its clinical course is slow compared to other diseases, which in turn results in late diagnosis of this condition. We present a case of a 37-year-old man who complained of palpitation for about 5 years, twice a week, at rest, with prolonged duration and low systemic output. Auscultation revealed irregular heart rhythm characterized by extrasystoles with a tricuspid systolic murmur grade $5+/ 6$ and worsening on inspiration. Clinical spectrum is variable and depends on the severity of defects and associated anatomical changes. In patients who have reached adulthood, symptoms usually present as progressive cyanosis, exercise intolerance, right heart failure, and arrhythmias. In Brazil, identification of this congenital disease usually occurs in a more adult phase, affecting the prognosis and survival of patients.

Keywords: Ebstein anomaly; Adult; Tricuspid valve insufficiency; Echocardiography

\section{RESUMO}

Anomalia de Ebstein é a quarta cardiopatia cianótica com maior frequência no período neonatal, cuja evolução clínica é lenta em comparação com outros tipos de doenças, o que, por sua vez, resulta no diagnóstico tardio. Apresentamos o caso de um homem de 37 anos, com queixa de palpitações por cerca de cinco anos, duas vezes por semana, em repouso, com duração prolongada e com baixo débito sistêmico. A ausculta revelou ritmo cardíaco irregular por extra-sístoles com sopro sistólico na tricúspide, $5+/ 6$ piora na inspiração. O espectro clínico é variável e ocorre de acordo com a gravidade dos defeitos e alterações anatômicas associadas. Pacientes que atingiram a idade adulta, os sintomas geralmente se apresentam como cianose progressiva, intolerância ao exercício, insuficiência cardíaca direita e arritmias. A realidade brasileira é que a identificação dessa doença congênita persiste em uma fase adulta, afetando o prognóstico e a sobrevida desses pacientes.

Palavras-chave: Anomalia de Ebstein; Adulto; Insuficiência da válvula tricúspide; Ecocardiografia

\section{INTRODUCTION}

Ebstein anomaly has a genetic basis and is found in $<1 \%$ of all patients with congenital defects. There is no prevalence of a particular sex. It is a special form of tricuspid valve dysplasia, characterized by downward displacement of the septal leaflet and atrialization of the right ventricle ${ }^{1}$. In addition to further deterioration of ventricular function, it has been associated with other heart congenital disorders that can trigger arrhythmias that are difficult to control, and those with highest incidence are atrial septal defect, corrected transposition of the great vessels, and hypoplasia of the right ventricular outflow tract ${ }^{2}$. 
This is the fourth most frequent cyanotic heart disease in the neonatal period, and its clinical course is slow compared to other diseases, which in turn results in late diagnosis of this condition. The pathological features may vary depending on the severity of valvular disease and other abnormalities present in each case, with cyanosis as the predominant manifestation, as well as conduction disorders associated with paroxysmal tachyarrhythmias ${ }^{2,3}$.

Thus, in view of this prolonged course and clinical diversity, identification of patients is usually suspected by changes shown on electrocardiogram and confirmed by echocardiography, thus enabling targeted and effective therapy with improvement of prognostic parameters. This is based on early clinical intervention aimed at reversing signs of hypoxia and increasing quality of life, but refractory or more severe cases may require repair or replacement of the tricuspid valve ${ }^{2}$. The cone technique shows more favorable outcomes, especially in the short and long term in the adult age group. Moreover, current data suggest a low percentage of medium-term hospital mortality in the neonatal group in large series ${ }^{4,5}$.

\section{Case report}

A37-year-old man came to our cardiology outpatient service complaining of palpitation for about 5 years, twice a week, at rest, with prolonged duration and low systemic output. In the periods between symptoms, the patient was New York Heart Association (NYHA) functional class I. On physical examination, auscultation revealed irregular heart rhythm characterized by extrasystoles with a tricuspid systolic murmur grade $5+/ 6$ and worsening on inspiration, as well as evidence of hepatojugular reflux on liver palpation. There was no evidence of jugular venous distension at 30-degree angle. At the time, we prescribed sotalol and digoxin. On Holter monitoring, we observed the presence of frequent monomorphic and paired bigeminal ventricular ectopy predominantly during wakefulness, not showing any tachy- or bradyarrhythmias. The patient was in ongoing use of sotalol. On echocardiogram: enlargement of the right atrium, right ventricular hypertrophy with signs of volume overload and preserved global systolic function. Tricuspid valve had a displaced septal leaflet and a redundant anterior leaflet. A color Doppler ultrasound revealed significant tricuspid regurgitation with systolic reversal of suprahepatic vein flow. Echocardiographic diagnosis was Ebstein anomaly with significant tricuspid insufficiency of normal right ventricular systolic function. The patient was then prescribed metoprolol and furosemide on alternate days, with partial improvement of arrhythmic symptoms, and was referred to the National Institute of Cardiology (Instituto Nacional de Cardiologia, INC) for correction surgery.

\section{DISCUSSION}

The origin of Ebstein anomaly is unknown, although genetic factors have been reported. Some studies claim that this anomaly is more frequent in homozygous twins in families with a history of congenital heart disease and pregnant women exposed to benzodiazepines or lithium ${ }^{6}$. Clinical spectrum is variable and depends on the severity of defects and associated anatomical changes. Because of that, the diagnosis of Ebstein anomaly in Brazil prevails between the 2nd and 3rd decades of life. In patients who have reached adulthood, symptoms usually present as progressive cyanosis, exercise intolerance, right heart failure, and arrhythmias ${ }^{2,3,7}$.

Physical examination may reveal, at first, low heart noise and cardiac systolic murmur associated with tricuspid regurgitation. Immediately following the heart noise, there may be, with great variation, from a second normal noise to a single noise until its paradoxical division. Presence of B3 is frequent. In children over 10 years of age, arrhythmias may occur ${ }^{3,8}$. Similar to cases described in the literature, in this case report the patient had an irregular heart rhythm characterized by extrasystoles with a tricuspid systolic murmur grade $5+/ 6$ and worsening on inspiration. However, the patient sought medical care belatedly, given that he had palpitations for about 5 years.

The surgical approaches for Ebstein anomaly consider specific cases: NYHA functional class III or IV symptomatic patients; NYHA functional class I and II patients with cardiomegaly; presence of a cardiothoracic index of 0.65 or higher; polycythemia with presence of significant cyanosis; events of paradoxical embolism; patient with uncontrollable tachycardia and accessory atrioventricular bundle ${ }^{9}$. Because the patient had reported palpitations for over 5 years with clinical signs of tricuspid regurgitation, the outpatient team preferred referring him to the INC cardiac surgery service for a surgical approach.

For the approach, the cone technique devised by Silva et al. ${ }^{10}$ is the most suitable. This technique brings the leaflets of the tricuspid valve to the true ring, making the longitudinal and level plication of the atrialized right ventricle. This approach adds an advantage to the leaflet for its coaptation, and this restores the geometry and function of the right ventricle, thus avoiding the use of a prosthetic ring ${ }^{4,10}$.

In this sense, it allows tricuspid annulus growth and flexibility associated with low hospital mortality by effectively and permanently correcting tricuspid regurgitation, restoring the functional area of the right ventricle, and allowing reverse heart remodeling and clinical improvement in most patients, in the long run ${ }^{11}$.

In Brazil, identification of this congenital disease usually occurs in a more adult phase, affecting the prognosis and survival of patients. Thus, in facilities far from major centers, differential diagnosis for Ebstein anomaly becomes crucial to reduce the morbidity 
and mortality rates of patients and then change this common scenario in Brazil.

\section{Funding}

This research did not receive any specific grant from funding agencies in the public, commercial, or notfor-profit sectors.

\section{Conflicts of Interest}

All authors of this review, namely Adail Orrith Liborio Neto, Rogerio Muylaert de Carvalho Britto, Otávio Defanti Ramos, and Mirelle da Silva Cruz Defanti, declare that they have no conflict of interest regarding the execution and publication of this work.

\section{REFERENCES}

1. Yuan SM. Ebstein's Anomaly: Genetics, Clinical Manifestations, and Management. Pediatr Neonatol. 2017;58(3): 211-5.

2. Almeida MMR, Tolentino FDS, Costa LVG, Quirino CMJ, Linhares BN, Teixeira AA. Anomalia de Ebstein: relato de caso. Rev Med Saude Brasilia. 2016;5(2):246-54

3. Jorge JC, Pires BLS, Rodrigues FAL. Ebstein anomaly: a case report. Rev Med Minas Gerais. 2012;22(4): S29-33.

4. Silva GVRD, Miana LA, LF Caneo, Turquetto ALR, Tanamati C, Penha JG, et al. Early and Long-Term Outcomes of Surgical Treatment of Ebstein's Anomaly. Braz J Cardiovasc Surg. 2019;34(5):511-6.
5. Guilhen JC, Silva JP, Fonseca L, Baumgratz JF, Bezerra RF, Castro RM. Late Cone Cirrugia Income For Newborn Ebstein. In: Summary of Communications XXV Brazilian Congress of Cardiology and Cardiovascular Surgery Pediatric; 201831 Oct - 03 Nov; Maceió. Rio de Janeiro: Brazilian Archives of Cardiology; 2019.

6. Cedeño CFI, Mera AMM, García MCA, Guillem EMM. Anomaly Ebstein, presentación de un caso. Qhalikay. 2017;1(2):44-51.

7. Jordán-Ríos A, Magaña-Bailón E, Martínez-Aguilar M, Maury-Ordaz S, Juárez-Orozco LE, Jiménez-Niño A, et al. Ebstein's anomaly. Rev Mex Cardiol. 2014;25(2):82-5.
8. Martínez-García G, Montero-García R, Cruz-Rodríguez L, CárdenasFernández Y, Hernández-González A. Ebstein Anomaly en edad adult. Rev Cubana Med Mil. 2009;38(3-4):91-100.

9. Pinasco GC, Rocha LF, Rocha LF, Lougon MH, Fiorio LM, Santos LS, et al. Ebstein's anomaly: A Case Report. Int Arch Med. 2016;9(233):1-6.

10. Silva JP, Baumgratz JF, Fonseca L, Afiune JY, Franchi SM, Lopes LL, et al. Ebstein's anomaly. Results of the conical reconstruction of the tricuspid valve. Arq Bras Cardiol. 2004;82(3):217-20.

11. Silva JP, Smith LF, Moreira LFP, Lopez LM, Franchi SM, Lianza AC, et al. The cone technics to correct Ebstein's anomaly: immediate and long term results. Arq Bras Cardiol. 2011;97(3):199-208. 